\title{
Frei Betto, uma vida entre a Igreja e a política
}

\section{Frei Betto, a Life between the Church and Politics}

\author{
ERNESTO BOHOSLAVSKY ${ }^{1}$ http://orcid.org/0000-0002-2453-3632 \\ ${ }^{1}$ Universidad Nacional de General Sarmiento \\ Oficina 5111, J. M. Gutiérrez 1150 \\ (1613) Los Polvorines, Província de Buenos Aires, Argentina \\ ebohosla@ungs.edu.ar
}

Obra resenhada

FREIRE, Américo; SYDOW, Evanize. Frei Betto, biografia. Rio de Janeiro: Civilização Brasileira, 2016. 448p.

O recente livro de Freire e Sydow é uma contribuição extremamente valiosa para a compreensão de alguns fenômenos políticos do último meio século do Brasil. A biografia nos permite perceber a profunda interligação entre as atividades intelectuais e pastorais e as práticas políticas de Frei Betto, desde meados da década de 1960 até hoje. Frei Betto parece ter estado presente sempre que algo novo aconteceu na política brasileira: ele foi a ponte entre a Igreja paulistana e o líder guerrilheiro clandestino Carlos Marighella no final dos anos 60, tendo passado quatro anos na prisão durante a ditadura por causa dessas tarefas; participou das comunidades eclesiais de base em vários estados depois de sair da cadeia; morou em uma favela em Vitória; fez parte das greves dos metalúrgicos do $\mathrm{ABC}$ em 1980; posteriormente, permaneceu próximo ao Partido dos Trabalhadores (PT) e a Lula e, finalmente, acabou envolvido

Recebido: 22 jul. 2018 | Aceito: 28 jul. 2018

http://dx.doi.org/10.1590/0104-87752018000300012

Varia Historia, Belo Horizonte, vol. 34, n. 66, p. 855-858, set/dez 2018 
na execução do Programa 'Fome Zero' nos governos do PT. Enquanto fazia tudo isso, tornava-se uma das figuras intelectuais brasileiras mais lidas e reconhecidas fora do Brasil, juntamente com Leonardo Boff e Paulo Freire, com os quais teve inúmeros contatos e intercâmbios e compartilhava o pertencimento à galáxia do catolicismo brasileiro em diálogo com tradições marxistas e críticas.

A primeira parte da biografia é organizada de acordo com uma rota cronológica, que começa com referências aos avós do frade e termina com suas últimas iniciativas políticas e literárias na segunda década do século XXI. A segunda metade do livro, contém capítulos temáticos: sobre a participação na imprensa, sua produção literária, suas amizades e sua vida cotidiana atual. Uma interessante seleção de fotografias nos permite ver algumas das trajetórias e ligações de Betto dentro e fora do Brasil e dentro e fora da Igreja Católica. O trabalho baseia-se na consulta da ampla produção intelectual e política do biografado, cartas pessoais, documentação jornalística e jurídica e, claro, dezenas de testemunhos recolhidos no Brasil, Argentina, Cuba, França e Nicarágua, produzidos por homens e mulheres que tiveram ligações com o dominicano em suas numerosas iniciativas políticas, eclesiásticas e educacionais. Nesse sentido, o livro oferece pistas para uma reconstrução das redes editoriais, jornalísticas, políticas e religiosas (principalmente latino-americanas) nas quais participou Frei Betto desde finais dos anos 60 .

Trata-se de um livro explicitamente favorável a Frei Betto: os entrevistados são unanimemente solidários, coincidentes na avaliação e nas memórias sobre o biografado. Isso impede que o leitor perceba as dissidências interpretativas que possam existir sobre Frei Betto, suas práticas políticas e seu nível de participação e envolvimento políticos (com a exceção do capítulo 20, que inclui as críticas e amarguras geradas por sua saída do primeiro governo Lula, em 2004, e a publicação do livro A mosca azul, em 2006). Essa impressão é confirmada pelo fato de que o prefácio do livro foi escrito por Fidel Castro, explicitamente amigo do frade: em 1985, como resultado de longas conversas gravadas em Havanna, Frei Betto publicou o livro Fidel e a Religião, que fazia parte da longa lista de seus esforços feitos para aproximar as posições teóricas 
e organizacionais do marxismo e do catolicismo (Betto, 1985). Talvez uma consulta a ocasionais detratores políticos, sindicais ou dentro da Igreja teria contribuído para detectar ou destacar algumas facetas ou avaliações mais críticas ou negativas sobre sua trajetória. A figura de Frei Betto torna-se neste livro, então, passível de leituras apologéticas. Em parte, isso é o resultado também da relevância do próprio biografado neste projeto editorial, no qual teve um envolvimento entusiasmado desde o início.

Os autores mostram vários elementos da vida econômica e social da família do frade que tiveram um papel crucial na trajetória de Frei Betto: um tio general do Exército e um pai juiz ajudaram a evitar a tortura física que sofreram outros clérigos sob o AI-5; pertencer a altos estratos profissionais da sociedade mineira foi fundamental para sua formação intelectual e para a posse de recursos retóricos que ajudaram construir uma carreira muito bem sucedida no mercado literário no Brasil. Vale considerar, por exemplo, que os próprios autores agradecem à agente literária de Betto (Freire; Sydow, 2016, p.405). Quantos autores da esquerda e frades têm um "agente literário"? Isto não é para apontar essas questões como se fossem estigmas, mas porque fatores como a estrutura da Igreja, do campo literário ou a distribuição desigual de bens simbólicos e materiais ao longo de linhas étnicas, de gênero e regionais no século XX no Brasil contribuem muito para uma compreensão mais precisa da impressionante carreira de Frei Betto. Isso ajudaria a compensar a importância que os autores atribuem a fatores mais individuais e contingentes, como as enormes virtudes pessoais do sujeito biografado.

Este livro será de enorme interesse para um público não especializado, interessado em conhecer os elementos centrais da evolução histórica do Brasil desde a ditadura até o presente. Aqueles que desejam conhecer mais a radicalização dos católicos nos anos 60 vão encontrar chaves sobre o rapidíssimo processo pelo qual muitos jovens passaram da Juventude Estudantil Católica para a resistência armada. Mas também vão achar pistas sobre os movimentos populares nos anos $70 \mathrm{e}$ as ligações com a Teologia da Libertação e com projetos educativos radicais. Muitas das características da política durante o começo da Nova 
República nos anos 80 e da política pública dos governos do PT são mais bem compreendidas a partir desta biografia, que consegue mostrar que Frei Betto foi uma figura animada, inteligente e criativa, não escapando nunca ao engajamento em relação aos problemas de seu tempo.

\section{REFERÊNCIAS BIBLIOGRÁFICAS}

FREIRE, Américo; SYDOW, Evanize. Frei Betto, biografia. Rio de Janeiro: Civilização Brasileira: 2016.

BETTO, Frei. Fidel e a religião. São Paulo: Brasiliense, 1985. 